Rethinking Urban Democracy in South Asia

\title{
Tej City. Protests in Mumbai, 1988-2008
}

\author{
Djallal G. Heuzé
}

\section{(2) OpenEdition}

\section{Journals}

Electronic version

URL: http://journals.openedition.org/samaj/3213

DOI: 10.4000/samaj.3213

ISSN: 1960-6060

\section{Publisher}

Association pour la recherche sur l'Asie du Sud (ARAS)

\section{Electronic reference}

Djallal G. Heuzé, «Tej City. Protests in Mumbai, 1988-2008», South Asia Multidisciplinary Academic Journal [Online], 5 | 2011, Online since 30 December 2011, connection on 30 April 2019. URL : http:// journals.openedition.org/samaj/3213 ; DOI : 10.4000/samaj.3213

This text was automatically generated on 30 April 2019.

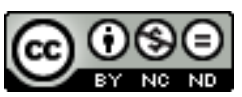

This work is licensed under a Creative Commons Attribution-NonCommercial-NoDerivatives 4.0 International License. 


\title{
Tej City. Protests in Mumbai, 1988-2008
}

\author{
Djallal G. Heuzé
}

Mumbai, the largest metropolis in India (18.4 million in 2011), has a long tradition of protests. ${ }^{1}$ In this paper I argue that urban protests are social struggles, which take the city as their framework, and, at least to a certain extent, as their topic. Some protests are not street-centred but the majority of them develop in the streets. They are related to direct action but they are not centred on violence. This implies that petitions and other peaceful means of expression as well as riots, although connected to a certain extent to urban protests, are liminal to this type of social action. Yet in the present conditions, direct actions which are not riots can very often turn violent. It would be interesting to compare present day Mumbai with other large cities of the south, such as Cairo, and also with the past situation of a large metropolis like Paris, for example between 1850 and 1950. There are very large industrial and workers concentrations, which are confronted with problems-high number of migrants, housing problems and tensions between rich and poor as well as between the state and citizens. However, we shall see that there are specific Indian and Mumbai peculiarities. I will describe and briefly analyze the diverse kinds of protests in relation to urban space and try to understand the dynamics of these actions. I shall also propose a typology of the protests. A large part of the information provided here comes from fieldwork conducted in Mumbai between 1979 and 2009. I was primarily interested in the workers of the central areas (Lalbag-Parel-Dadar) and of the suburbs and later became increasingly interested in the Dalits, ${ }^{2}$ Shiv Sainiks (Members of the Shiv Sena party) and Muslims. ${ }^{3}$ The methodology was mainly anthropological and focused on the working classes, youth and the sympathizers of the Shiv Sena.

The city became a workers' concentration in the second half of the $19^{\text {th }}$ century. There was a fundamental tripartition between the white town, in the southern part of the peninsula, the black town, comprising important commercial districts in the southern and south-western part of the present city, and the suburbs which were located in the present centre, between Byculla and Dadar (Tindall 1982). During the fifties and sixties new suburbs and a galaxy of slums changed the face of the city; the mills dominated the 
Lalabag Parel area emerging as a geographical centre, the south being the business and political centre. The city remained geographically fragmented and socially segmented.

One century ago, with large demonstrations opposing the imprisonment of the nationalist leader B. G. Tilak in 1908, the city began to be famed as a site of resistance. Colonial authorities abhorred this assertive character. For the natives, among whom there were many industrial workers migrating from the countryside, Mumbai (Bombay at that time) had tejas, a kind of dynamic and sacred energy. Tejas was the energy of sacrifice in the Vedic world. It cannot be said that today 'Mumbaikars' refer to this old sacred notion consciously but tej is not an ordinary word. The same could be said for tamasha, a notion associated with the Samkhya Hindu school of learning which designates a dark, passive energy. Tamasha is used to describe riots and disorder (as well as festive activities). ${ }^{4}$ The persistence and the reinterpretation of these old notions help to understand the complex fabric which is present in Mumbai. Meanwhile, the elites of the metropolis and some other intermediary groups began to invent the image of a harmonious city. Peace, especially social peace, was necessary for trade. Even industrialists had the traders' mentality. The elites also wanted their town to become the model of 'modern India'. Finally, many rich people considered the place as a kind of pleasant urban club. These rather conflicting views about the city, the tej in revolt and the dream of harmony, had long term consequences (Patel and Thorner 1995).

Urban protests multiplied after World War I. The first of a series of fourteen general strikes in the cotton industry erupted in 1918. Then Mumbai people were deeply involved in the national movement (especially in 1922, 1931, 1942, 1946), the city gaining a reputation for militancy and violence. So-called communal ${ }^{5}$ riots also came to the fore (especially in 1929 and 1946). After independence, the 'Prime city of India' ${ }^{3}$ was strongly divided over the issue of the creation of the new state of Maharashtra. In 1960, the movement for a Marathi-based province was successful and Mumbai became the capital city of this new state. The most violent events related to this struggle took place in the city in $1955 .^{7}$ In 1960, after the first large-scale migration, which led to a two-fold increase in the population, Mumbai was a metropolis on the verge of disruption. Mill owners were not interested in building affordable housing for their workers and permitted the building of unofficial slums and hutments on their large landholdings. Congress Party ${ }^{8}$ politicians, dominant at that time, did the same on public space for electoral purposes. Yet, the town had one of the best systems of mass transportation and essential services in India. Today, with a population increase of $400 \%$ since 1960 , despite recent investments in roads, it is almost the same infrastructure that continues to serve the city ${ }^{9}$ (Patel and Masselos 2003).

After sketching this rapid background, I will now turn to a series of questions that this paper tries to address: are urban struggles successful? Is it possible to classify them? Who protests and against whom or what? Is there anything which could be termed 'the people' of Mumbai? Is there a 'civil society'? What are the roles of NGOs and political movements? What about the popular dimension? Is Mumbai a 'globalized city' and, if this is the case, what are the consequences on urban protests?

\section{The terrible eighties}

In the sixties and seventies, the city was confronted with a wide range of social movements and urban protests. Labour unions were assertive. Born in the sixties, the 
Shiv Sena was in itself a continuous source of protests. Using general strikes, demonstrations, mass meetings and many other means for social intervention in the metropolis, shaped by the city's toughness (tejas), it made its presence continuously felt, with the noticeable exception of the Emergency period (1975-1977). Intervening at different levels but particularly well rooted at the local level, the Shiv Sena inaugurated a very specific practice. It was a mix of a reinvented and simplified Marathi culture and 'mediatized' assertion (Heuzé 1994). Direct action in the streets was a basis of the movement (Eckert 2003). It mobilized several categories of people ${ }^{10}$ as well as noticeable parts of the Maharashtrian petty bourgeoisie. ${ }^{11}$ Besides 'sons of the soil'12 issues, the Shiv Sena mainly focused on urban problems. It got stronger in the middle of the eighties (Gupta 1982, Purandare 1999).

The period was marked, in $1981-1983,{ }^{13}$ by the widespread, long textile strike and its failure. The strike came after a series of workers' movements. It was connected with the rise of an independent union leader, named Datta Samant. ${ }^{14}$ People like Samant proposed to lead strikes and got results by using strong-arm techniques and practising innovative methods. In 1989, this independent leadership was on the defensive but it remained strong. Datta Samant, who was also a Member of Parliament, had still about 250,000 members in his unions. Yet the pressure of unemployment (about 400,000 unemployed, including 100,000 textile workers) had begun to make the work of unions difficult. Since the dramatic end of the textile strike, employers often resorted to lock-outs. The last great manifestation of workers' militancy, the long strike of Hindustan Lever in 1987, could not break the strong association between the government, media and employers that was able to crush the textile strike (Van Wersch 1992, Heuzé 1987).

Mumbai had a rather numerous and well-organized police force. It was considered as less corrupt and more efficient than the forces of the northern states, comprising the city capital of Delhi. Yet it had specific problems. The Mumbai police force is class-biased and is against the poor. It has also, due to its recruitment methods, a pro-Maharashtrian and Hindu leaning. In August 1982, during the textile strike, the police revolted (about union problems). This revolt was crushed by the Special Reserve Police of Maharashtra, wellknown for their violence. There was not a year without one or several occurrences of shootings and lathi (stick) charges, with human casualties. This conditioned for a long time the specific character of urban protests in the city. The police are nonetheless able to negotiate. There are complicated deals between politicians, protesters, police and the bureaucracy. Many expressions of public outrage do not lead to confrontation.

Displacement of shanties and hutments began in Mumbai on a large scale at the beginning of the eighties. In 1981, $48 \%$ of the inhabitants ( 8 million) were living in slums and $20 \%$ in degraded tenements. The metropolis had become a city of slums during the seventies. Some of these settlements had a legal status. In 1982, Mr Ketkar, the manager of the Taj Mahal Hotel in South Mumbai, openly dared to announce his intention to have the city cleared of its poor. ${ }^{15}$ It was quite an innovative utterance at that time.

During the seventies there had been a regular influx of petty rich and middle income groups coming from the small towns of Maharashtra and from other states of India. They had problems when confronted with the large and increasing population of slumdwellers. It was not very easy for them to integrate. The prices of real estate began to increase, essential services and transportation systems were collapsing and there was a terrible lack of amenities such as parks. Resentment became an important feature of these groups. It was to express itself partially with the 'Saffron Wave' (Hansen 1999). 
On the other hand, the metropolis was divided by the nature of its elites. The primitive groups of highly 'Anglicized' industrialists and administrators of Gujarati and Parsi origin had given way to Tamil, Hindi and also Marathi-speaking people. The latter were especially important in the political world and the bureaucracy. There were also important Muslim trading communities. The city remained confronted with tensions between elite groups, who did not speak the local language and would have preferred Mumbai to stay out of Maharashtra, and 'subaltern elites'16 that promoted in various ways the Maharashtrian cause. ${ }^{17}$ Urban space was a complicated fabric of communities and religions but the Muslim minority (about 15\%) and the minority of people originating from the northern state of Uttar Pradesh (about 12\%, part of whom were Muslims) constituted particularly large groups asserting specific cultures. ${ }^{18}$

During the eighties, the tensions between Marathi-speaking people (a relative majority of about $42 \%$ in 1981) and others was not central. The spirit of the Saffron Wave began to make itself felt in 1981, after the mass conversion of former Untouchables in Minakshipuram (Tamil Nadu). The metropolis was for long a very sensitive ground for cultural issues, religious assertions and community-centred controversies. There was a trend towards overcoming their divisions among various Hindu communities throughout the eighties. It was a politico-religious and identity-centred process, especially important among the young. The tangle of Penjab ${ }^{19}$ and the killings of Hindus by young Sikh militants had important consequences despite the relatively small number of Sikhs in Mumbai. In $1984^{20}$ it was the faraway suburb of Bhivandi which burned for the second time (the first was in 1970). There were Hindu-Muslim riots in other suburbs. The Shiv Sena turned officially 'saffron' at this time and created the Hindu Mahasangh. Five years later, at the time of the beginning of our study, it associated itself with the BJP (Bharatiya Janata Party), an alliance which still exists today.

\section{Workers' protests}

Workers' protests of the past twenty years in Mumbai have been characterized by several trends.

The first was a global recession. Demonstrations (morcha), fasts (dharna) and other occurrences of protest were less numerous. They did not give birth to movements and the support of other social strata of the population was limited. This evolution was symbolized by the assassination of Datta Samant in January 1997, probably by henchmen of an employer. ${ }^{21}$

The recession of workers' protests is connected to several processes.

There was an important change of attitude by employers. They were strongly organized in syndicates and associations, which systematically opposed the workers' demands and organized lock-outs. In some occurrences, lock-outs led to protests. There were demonstrations in front of the Mantralaya (the seat of the State government) or the Vidhan Sabha (the State's legislative assembly) ${ }^{22}$ or in front of the employers' federations. These demonstrations were promptly dispersed by the police. They hardly had time to 'make news'.

A second important feature was the speeding up of the removal of factories from the city and even the suburbs. Several units were split in order to reopen in the 'informal sector' 23 employing only women and casual workers (there are cases of this kind in Malad, 
Bhivandi ${ }^{24}$ etc.). Other factories went out to Gujarat or Madhya Pradesh. ${ }^{25}$ The development of the informal sector and the rise of unemployment had a very strong impact on the workers' morale. Many of them were disinclined to indulge in protest, even when there was real resentment (Heuzé 2001).

The rise of Shiv Sena unions, which registered a three-fold increase between 1985 and 1997, was another striking feature of the situation. The Bharatya Kamgar Sena, the Shramik Sena and others ${ }^{26}$ were opposed to strikes. They did not usually motivate the workers to organize protests. This new kind of union culture wanted to be 'constructive' by delivering management courses to workers and struggling for productivity. They organized numerous meetings of workers but these were mainly festive. Yet in some cases, dharna and morcha structured by these unions were concerned with issues of employment and dismissal.

The assertion of conservative unions connected with the 'Mafia' gangs and their politics was another hurdle to the expression of workers' protests. Several such movements arose in central Mumbai (Girangaon) and in the suburbs. Trade unionists like Sachir Ahir, nephew of the notorious gangster Arun Gavli, were systematically connected with conservative federations (in this case the Congress Party-led INTUC). ${ }^{27}$

The announcement of the New Economic Policy in 1991 was a setback for workers' initiatives in an already depressed situation. Indeed it could be asserted that the Mumbai employers and the Shiv Sena unions had anticipated this policy on the labour front since the middle of the eighties.

Another feature was the growing importance of issues related to housing (infra) (Sundaram 1989). Many workers living in slums had to cope with the decline of their traditional joint and community living space in chawls, due to displacements and other issues. They were less prone and organized to intervene about labour-related protests.

An important peculiarity of the scene of labour protests in Mumbai during the period was the very efficient attempt of the printed media (radio was government-controlled) for devaluating or hiding existing protests. It was a reaction to the textile strike which had been treated in a very biased way by the newspapers but could not be ignored by them. A large majority of English and Marathi-medium newspapers were owned by private interests (business houses and press groups), opposed to protests as a whole and to workers' initiatives in particular. The Shiv Sena newspapers (Saamna, Marmik) had other reasons, especially nationalism and parochialism, for being biased. Noticeable papers that gave news about workers were Mahanagar (Hindi) and Navkal (Marathi). During the first wave of lock-outs (1983-1991), large newspapers decided to end the practice of having labour correspondents. ${ }^{28}$ They were replaced by 'economists', preaching the virtues of the 'free market' to the readership after the beginning of the NEP (New Economic Policy ${ }^{29}$ in 1991). More than a change of priority, the new approach illustrated a new turn in the class struggle. It was a specific attempt to 'de-materialize' the workers protests by not quoting them. There were usually 40 to 50 strikes a year in Mumbai and suburbs during our study period, some leading to violence, shooting and so on. It was not on a small scale. The metropolis was still a workers' stronghold in 2000 with over 500,000 jobs in the formal sector and more in the informal sector. This dimension was eliminated from the scene..$^{30}$ When allusions were made, they concerned so-called 'noxious' and 'antisocial' aspects such as the stoning of buses. This issue is important. Mumbai was a laboratory of free-market ideology and globalization practices. The issue of 'mediatisation' of protests assumed a specific role. Those who could play with the rules of consumerism and bring 
some glitter stayed in the 'hit parade' of the 'society of the spectacle' (Debord 1967). The others disappeared.

Two groups of workers could display sufficient strength to get their protests noticed.

The first were the permanent employees of the transportation system and some sections of municipal workers. There were several, short but very visible occurrences of bus and train strikes, such as in 1997, when roads were blocked and some buses destroyed by irate unionized BEST (Bombay Essential Services and Transports) ${ }^{31}$ workers. The same year, a large strike of sweepers made a strong impression. There were several other occurrences of demonstrations, blockades (rail roko, rasta roko) ${ }^{32}$ and shouting of slogans. Bank employees, who were at the centre of the financial world (the real world in the new globalized terms), could also have their demands noticed.

The struggle of the mill workers of Girangaon (central mills district) to get their wages arrears and their factories reopened was more or less echoed. There was perhaps a feeling of guilt among journalists who did so much to break the textile strike. A Girni Kamgar Sanghatan (Organization of Textile Workers) and a Girni Sangarsh Kamgar Samiti (Struggle Committee of Textile Workers) were created in 1995 and 1997. They associated outside personalities, mainly leftist well-wishers, some trade unions and ageing workers. They tried several times to enter the closed mills. They organized numerous demonstrations and sit-ins. The police were not too harsh with them and the media people found that it was a pathetic situation. Thousands of workers had wages arrears of tens of thousands of rupees. Another side of this protest concerned the land on which the textile mills were built (D'Monte 2002, Savery and Fernandez-Alvaro 2006). Workers' associations wanted to reserve it for social purposes. In 2005, the Girni Kamgar Sanghatan won a court case against builders and got 200 ha of land protected from private appetites. 33

\section{Housing struggles}

Housing was for long a central issue in Mumbai. Most places were overcrowded. Many buildings were collapsing. There was no housing policy for the poor. Municipal employees and policemen got quarters but others, especially casual workers, had no chance of getting a subsidized home. Between 1950 and 1980, the official policy was eradication of slums and the common practice was tolerance. The multiplication of hutments, slums and other casual housing was engineered by the people as well as by private slumlords. To stay in the vicinity of one's employment is a vital necessity for the poorer people who cannot afford to pay expensive fares for traveling. There was, for a long time, a global conflict between a 'bourgeois' ('middle class') Anglicized use of the city, implying ownership of an apartment (or house) and the use of private transportation devices, and other, multiple uses of the city ranging from the 'chawl' (partly collective but usually rented accommodation) ${ }^{34}$ to slums and sleeping in the streets or in the railway stations.

The situation has gone from bad to worse in the last twenty years. Hundreds of thousands of people have been obliged to quit convenient locations for faraway and often dangerous (marshy, under power grid, exposed to floods, etc.) zones. More than one million structures were destroyed, ${ }^{35}$ some of them 40 times. The rehabilitation of displaced families was generally a cruel joke. Many colonies, such as Mavjhani, Mankhurd and Dahisar, are too far away and devoid of facilities. Municipality, state government, railways and private agencies colluded to aggravate the displacement process. 
Reactions were more and more scattered. The first wave of displacement, during the 1981 monsoon, induced massive reaction, uniting leftists, unionists, displaced people and common citizens. The displacers-the rail authority-retracted. It did not happen again. This is not to say that there was no resistance in the face of the offensive of administrators, builders, shopkeepers and others. It existed, but it was weak. Due to the very fragmented nature of the scene, the question of a global movement has never arisen. Early in the morning, displacers attack isolated pockets of residents who do their best to save their belongings and have no time to try to get help.

Cases of protest are of two kinds. The first type concerns unorganized events. During the course of displacement, anger erupts and residents begin to throw stones or to fight the municipal corporation employees, policemen or other employees with sticks and stones. The police counter-attack and arrest a few people. The issue scarcely reaches the newspapers. In some cases such as the dramatic event of 1998 in the northern suburbs, the accidental death of a child or another member of the community during the demolition provokes a spurt of violence. As far as I know, these unorganized protests were a daily occurrence during the period. The corporation employees, dispatched in large number to these activities, got demoralized. Since some had parents living in slums, it was a terrible drama for them. Others became violent. It had a terrible impact on the social atmosphere in the city.

All parties, barring non-representative leftist ones, supported the displacement of casual residents. Politicians tried to demonstrate to the elites that they were responsible forces. They wanted to be 'modern'. The Shiv Sena, which had long inclined towards so-called rational 'modern' views, was for two decades equivocal regarding the fate of Maharashtrian slum dwellers. It turned frankly 'anti-slums' in 1985 when it got the majority in the municipal corporation assembly. Its slogan of 'Sundar (beautiful) Mumbai, Marathi Mumbai' echoed ${ }^{36}$ the 'clean and cosmopolitan Bombay' of the elites ${ }^{37}$ and opened the way for the 'globalized', investor-friendly city. When the Shiv Sena gained regional power and headed the government of Maharashtra, ten years later, it decided to set up a policy to eliminate the slum problem. This policy was to provide one million tenements for four million people but in reality, the Shiv Sena intensified the attacks against 'illegal' slum dwellers. Its housing policy failed miserably but the reduction of slums was concretized. Large waves of assault against slum dwellers took place in 1995, 1997 (35,000 houses destroyed at a time), 1998 and 1999. The fact that Manohar Joshi, the then chief minister, was a builder might have had some connection with this severity. When the Congress Party and the Nationalist Congress Party came back to power (they were also dominant in the municipal corporation between 1992 and 1997), the offensives against casual dwellers intensified. There were continuous attacks at the beginning of 2000, culminating in the 2005 campaign when 100,000 houses, giving shelter to 500,000 people, were destroyed. The creation of the Jawaharlal Nehru National Urban Renewal Mission in 2005 reinforced the connection between the state, the builders and the mill owners which had in their hands a very large tract of land in central Mumbai. Other destructions were to follow in 2007 with the new Maharashtra Housing Policy. These new policies, that entrusted the private sector with increasing incentives to lead rehabilitation and real estate projects, opened a large and deeply 'anti-people project'. One famous and contested example is the dream project of rehabilitating the centrally located slum of Dharavi that hosts 600,000 residents and 5000 industries. Nothing seems presently able to 
stop the assertion of private and corporate interests against the poor and their dwellings in the southern part of the city (Sharma 2000, Jacobson 2007).

Yet every party has voters. The destruction of slums is convenient when people have no voting cards but many have voting rights. ${ }^{38}$ At present, rich people want to destroy 'notified' (legalized) slums as well. The Shiv Sena leader found it easy to point his finger against migrants from Bangladesh, ${ }^{39}$ because they are Muslims and foreigners. Against illegal residents from Uttar Pradesh, it sometimes feels uneasy for this party, since Hindus and Shiv Sena voters are rather numerous among them.

Municipal corporation members (nagarsevak) have extensive networks of relations. Casual dwellers come to the office and ask for help, promising votes for the service. During large campaigns against 'illegal' dwellings at the time of the Shiv Sena tenure, I met several nagarsevak of the movement who opposed the demolitions. I also found these kinds of people in the Congress Party (both factions). Important groups of illegal residents lived for decades in their slums, for example in the vicinity of the docks, because they were protected by powerful Congress bosses. Leaders of smaller parties like the RPI (Republican Party of India), the Samajwadi Party and the Janata Dal, are systematically on the side of the displaced people, trying to gain popularity with this stance. ${ }^{40}$ Small-scale politicians have often taken the lead of morcha of evicted slum dwellers. Yet, this kind of action is not lasting. The interest of the local leaders is to get peace in their district and, as we have noticed, central instances of the parties increasingly oppose (illegal) slumdwellers. Political parties have a tough time between the pressures of the builders, the social Darwinist leaning of the elites, the fears of the petty bourgeoisie and, the weakest voices perhaps but the most numerous, the opinions of the slum dwellers.

The cause of displaced dwellers was never a popular one in Mumbai during the period. Actions were nonetheless undertaken by members of the 'lower middle class', and by some affluent people. Their arguments were multiple. For the Save Bombay Committee and several other groupings representative of the elites, the policy was destructive because the town was in need of workers and because it engineered social tensions. For an organization like the Nivara Hakk Suraksha Samiti (Committee for Justice and Safety of Housing, more or less leftist), housing was a civil right and it had to be protected like any other social right. The Samiti struggled to get this right included in the Constitution. ${ }^{41}$ Yet the committee was weak and had to become associated with other organizations, especially the bourgeois and elite ones, to get access to the media. The Youth for Unity and Voluntary Action, which struggled at the end of the nineties against the displacements engineered by the Shiv Sena-BJP government (BJP-backed organizations of evicted people exist also) was also promoted by 'lower middle class' people. SPARC (Society for the Promotion of Area Resource Centres) was another important NGO active on the scene.

The main personalities implicated in the struggles for displaced and evicted people were the actress Shabana Azmi, the old Gandhian Usha Mehta and the rich, Gujarati secretary of the Save Bombay Committee, Kisan Mehta. This triad gives a good indication of the nature of the motley and limited coalition of people trying to help poor displaced people ${ }^{42}$ in Mumbai. Medha Patkar, a Gandhian who led the struggle against the Narmada dam, came on the scene after 2000. ${ }^{43}$ Shabana Azmi had a particularly important role. The daughter of a communist activist, an actress and a Muslim, she has been on the side of the evictees since the beginning of the eighties. She appeared at demonstrations, organized meetings and was even able to transform fashionable events to plead the cause of the 
evictees, in 1998 for example when she spoke at a grand assembly awarding her a distinction.

In 2005-2007, following the serious worsening of the situation, there were numerous meetings, as well as morcha in front of the Mantralaya. Medha Patkar spoke against the 'Shanghaification' of Mumbai, ${ }^{44}$ leaders of the National Alliance of People's Movements (NAPM) and the Shahar Vikas Manch (Front for the Progress of the City) denounced the Mumbai Vision Plan, the Coastal Zone Regional Act, The Mumbai Development Plan, the Mumbai Urban Transport Project and the conclusions of the Mac Kinsey ${ }^{45}$ consulting firm as 'anti-poor' and anti-casual dweller initiatives. Since the intention of these initiatives was to reduce the proportion of slum dwelling from $60 \%$ to $10 \%$ without any investment in social housing, the assertions of the opponents were relevant.

The interventions of these organizations and personalities were unable to change the situation, which has become more and more unfavourable to slum dwellers. The evolution of the two main laws protecting the interests of the poor, regarding housing in Mumbai, is a good illustration. The Rent Act 1948, that regulates the rents of old buildings, is highly endangered. Several strong owners' associations want to abolish it. There were many protests about the scrapping of the Act but they were dispersed and hindered by political divisions. A specific case concerns chawl tenants. Many mill owners tried to get the dismissed workers of the closed mills thrown out of their small apartments (kholi). ${ }^{46}$ The law is on their side. Yet, these tenants resisted much better than those of the slums. They were more or less accustomed to unionism and they had better political connections. The Shiv Sena and the Congress Party local leaders stayed on their side. They founded the Mumbai Bhadekaru Sangh (Organisation of Mumbai's Tenants) in 1997, which was engineered by the father of a well-known Shiv Sainik (Shiv Sena activist).

The case of the second law, the ULCRA (Urban Land Ceiling Regulation Act) was similar. From the very beginning, the rich and the elites could prevent this law of 1976, the purpose of which was to spare land for social housing and public interest, from becoming effective. Yet it was a hindrance for builders and a boon for corrupt bureaucrats. The large-scale offensive against this 'socialistic' law began in the eighties. It never weakened. The New Economic Policy gave impulse to those who struggled against the law. Political parties were equivocal about it. It gave powers for state intervention and it was popular but authorities did not make use of it. Pressure from rich owners and the ideology of globalization, combined with the conditions imposed by the Central government funded Jawaharlal Nehru National Urban Renewal Program, proved stronger. It was abolished in 2007. The Shiv Sena, which did not act to enhance it during its period of influence, organized a demonstration to protest against the move. Small organizations, like the NAPM and Shahar Vikas Manch, personalities like Shabana Azmi, who wanted its effective application, also organized demonstrations.

There will be other protests about housing in Mumbai but the prospects for large scale and efficient mobilizations seem dim. The traumas of the past period have demonstrated that the evictees were unable to unite, their supporters in the 'petty bourgeoisie' being weak and divided. ${ }^{47}$ Regarding housing, the process of globalization of the city is heavily paid for by the popular milieus, in other words the majority of the population. Yet the people are not the central topic of the confrontation, as if there were no longer an overall entity associating industrial workers, street vendors and home-based workers. 


\section{Protests of hawkers}

The problems of hawkers are intimately connected with those of slum dwellers. Both issues concern public appropriation of space and access to means of living. Both types of people are confronted with a growing offensive by 'town cleaners' and partisans of a 'bourgeois' use of the city. Lastly, many street vendors live in slums and they are confronted with displacement in the workplace as well as at home.

There is a particular acrimony in the words and the deeds of the dominant classes and the rich about hawkers. It began ... in the $19^{\text {th }}$ century! Their resistance is much stronger than the protests of the slum dwellers. The Shiv Sena has been consistently on their side. ${ }^{48}$ The Shiv Sena-led municipal corporation granted hawking licences in large numbers. Places such as the Dadar station surroundings, near the Shiv Sena main office, were for decades packed with thousands of street hawkers. The organization considered that the struggle against unemployment and the interest of its members were more important than the pedestrians' comfort. It was also a question of money, since hawkers supported financially the Shiv Sena in numbers. In 1995, after getting regional power, the party converted itself partially to a more 'elitist' conception of the use of public space. A Shiv Sena leader like P. Navalkar ${ }^{49}$ thundered against street vendors. He was countered within the organization by local leaders favourable to the hawkers' cause and, outside the Shiv Sena, by irate mobs of vendors. The creation of the Zunka Bhaka program, a ploy intended to deliver cheap food for the 'common Maharashtrian man', was a major concession of the movement to street vendors.

There are unions of hawkers in Mumbai, the most noticeable being the Bombay (then Mumbai) Hawkers Union affiliated to the leftist ${ }^{50}$ Hind Mazdoor Panchayat (Suresh Kapile) and several Shiv Sena unions. Protests of hawkers were directed at the municipal corporation, the railways, which continually organized large-scale cleaning operations in the railway stations, and the police. They were commonly accompanied by petty violence. In some places such as Ambedkar Road (the main avenue in the central district), eviction of hawkers were a daily occurrence for years. The situation of hawkers has considerably worsened and the profession is on the defensive. They are considered as 'non-modern' and 'parasitic' elements by the rich. An important part of the tensions concerning hawking is connected with the opposition of large shopkeepers. ${ }^{51} \mathrm{~A}$ large clash took place at the Lohar Chawl in 2004 but there were many smaller incidents. Part of the hawkers' protest, which is much more assertive than the protest of slum evictees and does not interest Gandhians and artists, is taking place at the legal level, in the courts of justice. The journalist Olga Tellis is among the few who has consistently supported hawkers' struggles in Mumbai for more than 25 years. 300,000 hawkers feed one million people...

\section{Taxis and rickshaws}

Taxi men and rickshaw drivers (there are only motorized rickshaws, or three-wheelers, in Mumbai suburbs) are a considerable part of city life. They know the metropolis, they are as necessary as buses and trains and they are conscious of it. There are presently 75,000 rickshaws and about 50,000 taxis as opposed to some 3,000 buses. One third of the taxi men rent their vehicles. Another third are dependent on employers and cannot easily 
organize. Others are members of unions, associated with leftists (Bombay Autorickshaw Union) or the Shiv Sena. There are also independent unions.

Taxi men and rickshaw drivers fight alongside each other very rarely. During the past two decades, it has happened only locally, in the case of mob violence or police violence. Their main struggles are against the government, about fares, or against each other. In November 1997, taxi men organized a strike against the rickshaw drivers, finding them too numerous and pampered by the Shiv Sena government. Many taxi drivers come from Uttar Pradesh whereas a majority of rickshaw drivers are of Maharashtrian origin. A 'communal' contradiction is reinforced by a conflict of interest. There was a new strike in 1998 and several morcha were organized. The issue of new licences arose many times, at the level of taxi men as well as at the level of rickshaw drivers. Usually those who had licences protested against new entrants. There were several demonstrations and blockades of roads, against Congress Party-led governments as well as against Shiv SenaBJP led ones. Lorry drivers also organized several strikes, mainly against taxes and controls. They have created a strong lobby.

\section{Struggles for day-to-day survival}

Struggles for essential commodities-transportation being one of them, besides electricity, basic food, water and the cleaning of public space-have long been an important feature of life in Mumbai. They continue to be part of the scene.

Mrinal Gore, who led dozens of such struggles against price rises and paucity of essential commodities, was rebuffed in 1994 when she tried to come back to the 'good tough times' by organizing a morcha on similar issues. Few people came and the politician explained that the 'middle-class' people had become too rich, the poor being too busy with day-today survival. It may be true that a part of the lower middle classes enriched themselves. It seems possible that problems of food have become less acute than before, despite the fact that the situation of many has worsened, especially in the case of evictions. The appeal of Gore had also faded. In 1998 she denounced the fact that a firm had used one of 'her' demonstrations as the basis for an advertisement!

Yet, there were still demonstrations for kerosene, edible oil and complaints about the lack of vegetables (basic to the common man and woman's diet), especially onions. Fish was in short supply several times and there were local but numerous demonstrations as well as spontaneous outbursts in the queues at the Fair Price Shops (of the Public Distribution System). Shiv Sainiks 'stole' at least a truck of oil and another one of kerosene to get them distributed in the suburbs. This kind of propaganda, which is a radical form of protest, is an old practice of the organization. It apparently disappeared during the Shiv Sena's period in power (1995-2000) at the State level.

Numerous local demonstrations, at times structured by Shiv Sainiks or members of other organizations, focussed on the lack of power or drinking water. In 1999, for example, inhabitants of Bhayander ${ }^{52}$ protested violently against the lack of drinking water. They stopped trains and blocked roads, attacking buses and destroying several of them. A woman led the demonstrations. In 2004 it was the Shiv Sena which led such a struggle in a northern suburb, ransacking an administrative office. The attacks against officials and offices are a definite part of this kind of protests, especially when they are led by assertive forces such as the Shiv Sena or the Dalits (infra). 
These protests can be organized but there is a great deal of spontaneity in them. The main example is the ransacking of the train station of Thane by angry commuters in September 1995. They were tired of delays. Less dramatic examples of the same trend exist regarding trains and buses. It seems that Mumbaikars (Mumbai residents), who were never very patient, have become more and more demanding.

Among the recent types of protests taking place in the streets remain the numerous, small but insistent, protests against piles of rubbish. The cleaning system has not worked well for a long time but there is a change in people's awareness, and they no longer accept the situation. These protests are certainly more common among the petty rich people but others are more and more involved. They have led to an improvement in the service. In the slums, where it is often difficult to protest about essential services and maintenance problems, there are also local struggles. They mainly concern drinking water, bus services and toilets, since all these basic amenities are commonly lacking.

\section{Communal and community-related protests}

It is difficult to deal with 'communal' issues in Mumbai in brief. It is a complex topic and situations would need in-depth analysis as well as a discussion of categories in order to reach a minimum of understanding. However, it has to be dealt with in a synthetic work on urban protests. So-called 'communal' protests are a permanent problem in the popular milieus (slums and chawls) of the metropolis. Affluent classes affect to ignore them. It is an exercise in double-speak. Merchants and shopkeepers and many other rich people are deeply involved in (their own) community matters.

'Communal' issues are ways of expressing many other tensions in Mumbai. The successive defeats of industrial workers and slum-dwellers, the tensions over hawking and police oppression of the poor clearly facilitated the rise of tensions during the eighties. There was a continuous process of brutalization accompanied by the disappearance of people's organizations such as trade unions. It led, besides specific issues of the Saffron Wave, ${ }^{53}$ to several episodes of large-scale violence. Riots are also a self-destructive process of people devoid of hope. There is finally an internal logic to these events. In Mumbai, for decades, the annual festivals of Hindu deities and the Muslim Moharram (a festival) were so noisy and provocative that they acted as an introduction to riots. It is also true for Friday Muslim prayers in the streets. They are not protests per se but they have some features of a protest (Heuzé 2000a).

Near-rioting situations often occur in the metropolis. It is estimated that 300 events lead to group violence every year (police estimates in 1995). The management of riots is very important for the authorities. During the Shiv Sena-BJP government tenure (1995-2000), the government was disinclined to tolerate rioting situations but quite a few occurred. After this date, Shiv Sena and the like once more became trouble makers. Tensions arose between Biharis (people from the state of Bihar) ${ }^{54}$ and members of the Shiv Sena, on one side, and people from Uttar Pradesh and members of the Maharashtra Navnirman Sena (MNS) of Raj Thakre (a splinter group of the Shiv Sena which is on the rise) on the other side. The most important eruption of violence occurred in February 2008 when a meeting of Mulayam Singh Yadav (the leader of the socialist Samajwadi Party) provoked tensions around Dadar. The MNS men attacked taxi drivers, supposed to come from Uttar Pradesh, and members of the Samajwadi Party. The Shiv Sena of Bal Thakre condemned this violent action but it had long provided the fuel for provoking such violence... 
Other rioting was observed, opposing members of the Dalit community and the backward classes, as happened in 1989 in Chembur. Many other occurrences of group struggles, for space, status or employment, can be traced. Although newsmen have shunned workers' strikes, they are fond of spectacular street rioting. The vision of a harmonious cosmopolitan city is a cherished dream of the elites. It is a motto of the globalization era but it is only a dream.

Regarding Hindu-Muslim tensions, the main event was the double series of riots between December $6^{\text {th }} 1992$ and January $18^{\text {th }} 1993$. With about 800 casualties, aggravated by the 315 deaths in the bombing of the following March, 50,000 displaced people and thousands of houses and shops destroyed, it remains today in the popular memory (Padgaonkar 1993). It began as a massive unorganized protest of Muslim youth against the destruction of the Ayodhya mosque by Hindu nationalists. Many of the 227 dead were killed by police. In the 'second round' the Shiv Sena decided to avenge the ransacking of the city and the killing of some 45 Hindus by Muslim mobs. With the help of the BJP, it organized massive arti (fire ceremonies) -a kind of partly religious, partly political protests that had the effect of bringing tensions to new heights. After several provocations from the Muslim side, new large-scale rioting broke out on January 8 th and the Muslim community was at the receiving end, the police staying out of the scene after having been criticized. There were few protests against rioting. They were organized by the children of the elite schools, the Christian community and small groups of 'concerned citizens'. I repeat that the classification of riots as protests is questionable. Indeed many riots start as protests. The attitude of the state and its police is a determining factor.

\section{Symbolic issues}

Symbolic issues have an enormous importance in the history of Mumbai's protests. They concern mainly important groups associated with political parties which are also cultural organizations, the Marathi speakers and the Dalits. Muslims are also much concerned by symbolic issues. They are strongly associated with the questions of pride, collective identity and status (Heuzé 2000b).

The Marathi-speaking population and the very large group of $\mathrm{OBC}^{55}$ and Marathas ${ }^{56}$ belonging to the working classes and employees' strata have a very important experience of emotional mobilization. It began in the fifties with the creation of Maharashtra and the Samyukt Maharahstra Andolan..$^{57}$ It continued with the Shiv Sena after 1966. Other organizations, including the powerful Maratha Mahasangh (a caste association located in Dadar), also played a role in this mobilization. After addressing various issues such as Marathi theatre and cinema and the promotion of the Marathi language in the administration and firms, the movement of the Marathi-speaking population of Mumbai concentrated on two issues during the period studied.

The first one was the change of name from 'Bombay' to 'Mumbai' and the change of the names of streets, squares and monuments. There were many demonstrations, engineered by the Shiv Sena, but also others, regarding these issues prior to 1995. After this date, the name of 'Bombay' was abandoned and many places such as the Shivaji station (exVictoria) and the Shivaji airport got their present names.

Other symbolic issues, connected with Shivaji ${ }^{58}$ and Maharashtrian honour, arose several times. Huge demonstrations of Shiv Sainiks, supported by other people as well, protested 
about Shivaji's pride in the streets of Mumbai at the end of the eighties. A book terming Shivaji as a 'member of a backward caste' (he was a Maratha) was strongly condemned and publicly burnt. In the 1990s and 2000s there were other controversies regarding books or articles considered as derogatory to Shivaji. Other publications were burnt. In one occurrence, a book (by James Laine) was banned by the State government..$^{59}$ This was done by a Nationalist Congress Party-Congress government, since pressures from the Marathi-speaking lobby were effective on these parties as well. ${ }^{60}$

Another issue very strongly mobilized the Hindu community and especially militant Hindu nationalists (comprising the Shiv Sena) and the Dalit community, mainly consisting of Mahar (the caste of Dr Ambedkar). ${ }^{61}$ It was induced by the publication of Ambedkar's book, Riddles of Hinduism (a strongly anti-Hindu pamphlet) by the state government in 1988. Enormous demonstrations of Shiv Sainiks and others opposed the official publication of a book that criticized the characters of Ram and Sita, Hindu gods in the Ramayana epics. Mobilizing people from the whole of Maharashtra, the Dalit movement answered in support of Dr Ambedkar and there were even bigger demonstrations for getting the Riddles published.

Shiv Sainiks, among Hindus, and Muslims ${ }^{62}$ as a whole, display a strong tendency to mobilize with regard to identity-centred and pride-related issues. This tendency produces a kind of popular sub-culture, articulated around flags, loudspeakers, boards, party banners, temples and mosques. This culture is greatly despised by the elites, who complain about noise and lament about the reputation of the city in the eyes of foreign investors. Dalits, especially the neo-Buddhist Mahar community, demonstrate perhaps a deeper inclination to this mode of expression. The presence of Dr Ambedkar's samadhi (mausoleum) in Mumbai, the importance of the poetic and rebellious currents of the Dalit Panthers (born in Mumbai in 1973), the participation of Dalits in the Samyukt Maharashtra movement and the cooperation of many of them in the Shiv Sena are among the facts that encouraged the use of symbolic assertion in the streets by the Dalits. It permitted them to unite, when their political associations remained faction-ridden, ${ }^{63}$ to get the public attention by mobilizing the press and some intellectuals, and to enhance their status. Mumbai is a city where pride, violence and strength are deeply associated and globalization seems to reinforce the trend.

Since the beginning of the period studied, Dr Ambedkar's birthday (April 14 ${ }^{\text {th }}$ ) and the anniversary of his death (December $6^{\text {th }}$ ) have become moments of assertion through mass meetings associating demonstrations of strength with the expression of grievances.

Between 1983 and 1994, the main demand was the namantar (renaming) of Marathwada University that the Dalit leaders and intelligentsia wanted to become 'Ambedkar University'. The movement dates back to 1977. It turned violent in 1979, the local nonDalit and the Shiv Sena strongly opposing the move. ${ }^{64}$ Yet the Dalits and their struggle became more and more assertive, with the evolution of the politics of Maharashtra and the support of the Congress Party after 1991. There were numerous demonstrations in the metropolis at the beginning of the nineties. The fight assumed so much importance that the Congress Party-NCP-dominated government decided to change the name of Marathwada University in January 1994. This was done despite an upsurge of Marathas and other Hindus in Marathwada and a large bandh (general strike with street blockades) of the Shiv Sena in Mumbai. Several people were killed in Marathwada and dozens were injured in Mumbai during these events. Mumbai was the nexus of a symbolic struggle concerning a faraway educational institution because it had become a symbol for the 
whole Dalit community. The use of the 'cosmopolitan city' as an arena for political and symbolic assertion of the Dalit community was not a pleasant occurrence for the dominant elites ${ }^{65}$ Numerous supporters of the Congress-NCP combine were disgruntled with the namantar tangle, especially among the numerous Maratha community. There were street protests and meetings. The Dalit sensitivity about this question stayed alive for many years. For example, in 1995, a protest of activists of RPI and Dalit Mahasangh (another Dalit organization) stormed the Mantralaya because an official statement had forgotten to quote Dr Ambedkar's name when speaking about the University of Aurangabad (formally Marathwada).

There were many other symbolic and status-related issues in the field of Dalit politics in Mumbai during the 1988-2008 period. The question of desecration of Ambedkar's statues was permanent. These monuments, often erected in slums and poor people's localities, are not as numerous as in Uttar Pradesh ${ }^{66}$ but they are becoming an increasingly important incarnation of Dalit pride. A dramatic event occurred in 1997 in Ghatkopar (northern industrial suburb) when a statue of Ambedkar was garlanded with shoes. The reaction of the Dalit youth was violent. The police reaction was worse and eleven young men were slain by bullets. This kind of protest was related to the Shiv Sena-BJP government's poor relationship with the Dalit community. ${ }^{67}$ This relationship was soured when the regional government scrapped the Minorities Commission and stalled the work of the Shri Krishna Commission ${ }^{68}$ in January 1996. This event was followed by an enormous demonstration of Dalits. On February 26th, a total bandh was imposed on the city. Numerous buses were destroyed. The protest of Dalits against the scrapping of the Minorities Commission was hardly the expression of a deep commitment to Dalit-Muslim solidarity. Many Dalits took part in the riots of 1993 on the side of the Shiv Sena and Sangh Parivar ${ }^{69}$ and they greatly resented the bombs of March 1993 which were set by a Muslim underworld organization.

\section{Bourgeois, elite and 'middle class' protests}

NGO observers of the "Mumbaite"70 scene do not often talk about the protests of the rich, as if protests were the monopoly of the poor, downtrodden and working class people. It is misleading because the intervention of privileged people in the public sphere is important and revealing. Yet are we confronted with protests? They are scarcely taking place in the streets and they are not exactly direct actions. It is a liminal case but these actions have an important impact on the evolution of other kinds of protests. This is why they are included in this paper.

There are several reasons for this assertion of the 'bourgeois' classes of Mumbai in the field of protests during the past twenty years. The elites and dominant classes have a specific culture. They did not approve much of nationalism in the past. They consider themselves as 'globalized'. They are certainly more or less deeply Americanized. Many families have one or several members living in the US or the UK as students or workers. ${ }^{71}$ A part of the Gujarati elites ${ }^{72}$ wanted Mumbai (Bombay for them) to become a kind of Singapore. However the myth of Singapore does not only concern the Gujarati elite. The idea of an authoritarian, clean, rich state has been the main ideal of the rich for decades, 'Shanghai dreams' having recently replaced the Singapore vision. The city seems dirty. Criminals make the news. The present state of affairs seems shocking to the well-off 
classes, despite a low level of criminality ${ }^{73}$ and much better facilities than in other towns in India. They feel they have reasons for indulging in protests.

The rich and the petty rich of Mumbai are not only Gujarati. The city is so huge, affluent communities are so numerous and problems of the citizens are so acute that, about certain issues, important movements of the rich and the petty rich arise. There are about 2-3 million affluent people in a city of 18 million. These people can collude, at times, with small shopkeepers and high caste employees. They are numerous enough to induce mass protest movements. ${ }^{74}$ Among the less rich who live in faraway locations, in the vicinity of slums and polluted areas and who have to use a crumbling transportation system, problems may be particularly serious.

The protests of the rich and the petty rich are different from the tough (tej!) demonstrations of the Dalits, the Shiv Sena and the Muslims. They are not able to provoke bandh. For this reason perhaps, they are critical of the use of such methods, but they have an important advantage in the media sphere. When Shiv Sainiks or Dalits are 'obliged' to break windows and slash tyres to get media attention, any small committee of 'concerned citizens', self-representing the 'civil society', has no problems in bringing attention by organizing small meetings or symbolic dharna. Their feelings are explained at length in the columns of the press, like the anger of Tavleen Singh in the 1990s and 2000s. This columnist expressed relentlessly her disgust because Mumbai was not a 'world-class city'. While slum dwellers are fighting for survival, well-off citizens can discuss aesthetics and city planning, playing with the ideas of the architect C. Correa (formulated in 1965), comment on a new project for revamping the lamp posts on the avenues (1998) and lament about the state of affairs. The concept of 'civil society' proves once more to be unclear and able to induce a mythification of the scene of protests. The rich and the elite believe that they represent everybody and that they are victimized by the state and the politicians. Their interpretation of civil society is their belief that they, themselves, are the people. Indeed, the contradiction between the rich and the state is less important than their confrontation with populist politicians. They have influence everywhere in the bureaucratic sphere. Regarding their pretension to represent the overall interest of the people, it is clear, considering their anti-poor bias, that it is a rhetorical formula and an attempt at gaining the support of the petty rich.

The idea of cleaning Mumbai was presented as a 'protest of the citizens' and a sane reaction against corrupt politicians. This is perhaps the only level at which the rich and the cosmopolitan elite led a popular struggle. Yet corruption of politicians is a complicated issue. Politicians may cheat the state, they may rob their voters but they may also protect some groups against the greed of the bureaucracy (which is also corrupt). It is much easier for the rich than for the poor to bribe them. It must be underlined that the rich do not vote. They are scornful of democracy. Their direct and indirect action is their only way of influencing the situation. This was associated with the desire to 'green' the metropolis, where trees are very scarce, but those who talked about this were also those who introduced a lot of cars, especially SUVs, that are destroying the city structure (there is no space for many roads). In 1993 and the following years the elites mobilized 20,000 Scouts ${ }^{75}$ and the Rotary and Lions Clubs to fight against... betel spitting. They were supported by the municipal corporation and the State government.

A large majority of the well-off reacted against a proposal of the BMC (Brihan Mumbai Municipal Corporation) for the killing of stray dogs in the capital of Maharashtra (there were 1.2 million of them). In many places, residents demonstrated against hawkers, 
hutments and encroachments, as happened recently (2008) in Borivli where a satyagraha ${ }^{76}$ of pedestrians' targeted rickshaw and tea-shops. There was a stiff struggle for space between the slum dwellers and the residents. It was especially tense in places where residents are not so rich. Borivli is a faraway suburb. The residents fear for safety as well as for the value of their property. In central Mumbai there were also important tensions between the inhabitants of the chawls, who are, at the most, petty rich, and the remaining hutment dwellers. In 1998, in Borivli again, a group of residents succeeded in transforming 'a marshy haven for antisocial element' into 'a swanky recreation complex' (these are the terms of the newsmen), jogging for officers and permanent employees being considered more important than the survival of the poor. There are hundreds of such occurrences. The support of newsmen and newspaper owners for these kinds of initiatives cannot be overestimated. They were clearly a part of the struggle for the bourgeois use and appropriation of the city, generally presented as 'civic causes' or 'civil society assertions'. Associations like the 'Citizen's forum for the Protection of Public Space', the 'I love Mumbai Committee' and many others have been instrumental in this regard. If the slum dwellers are globally weak and unorganized, the rich and petty rich have multiplied citizens' associations, residents' committees and clubs. They have led demonstrations and organized meetings. In extreme cases, but Mumbai is a city of extremes, they organized fasts and satyagraha yet the most common means of action was the written petition and actions in the courts of justice..$^{77}$ The relation of the Mumbai rich, especially the petty rich, with the administrators is a complex mix of defiance, negotiation, lobbying and struggle for rights. The story of G.R. Khairnar, the well-known 'Mr Bulldozer" who destroyed thousands and thousands of hutments-and some greater buildings as well- refusing to bend in front of politicians' pressures, is typical of the dreams and fears of the Mumbai petty rich. He was a protest in himself, constantly defying enemies: bureaucrats, builders, illegal residents and politicians. In the nineties, Khairnar began a crusade against 'lazy municipal corporation employees'. He tried to impose a pocket union on them, fought ('valiantly' according to a press report) against 'filth' and 'antisocial' elements in Vasai and Virar (1992) and was finally dismissed by the Shiv Sena-BJP Corporation in 1997. In 1999 the Times of India reproduced the 'appeal of a silent majority to a civic jihad', the signatories supporting people like Khairnar and the 'beloved' police officer R.D. Tyagi. Several other administrators, policemen, municipal commissioners and jurists like Palkiwala, whom thousands and thousands of people went to hear in a stadium every year during the nineties, were the icons of the petty bourgeoisie during the study period. Globally the 'middle class' love the press and the law, especially when they are English, but they dislike elections and the political world.

The 'petty bourgeoisie' ('lower middle class') shared with their richer counterparts a complicated mix of fear and scorn regarding the 'common people' but contrary to them, they still voted in large number during the sixties and the seventies. There was then a growing alienation of the so-called 'middle classes' from the field of parliamentary democracy. The style of operation of the Shiv Sena in government, with the numerous cavalcades of official cars and the saffron flags posted everywhere, might have disgusted quite a few more. Afterwards, defiance kept growing. It manifested itself openly very recently with the attacks on the five-star hotels and the railway stations (November 2008) by Muslim Pakistan-trained elements. Unruly mobs of rich students and bourgeois women vilified the politicians who had been unable to protect them. A recent movie (Rang De Basanti, by Rakesh Omprakash Mehra, 2006) had prepared the way for this attack on politicians who are, it must be underlined, a part of the dominant classes. People went to 
the streets shouting that they would 'prefer a dog to a politician'. They had already preferred dogs to slum-dwellers.

\section{Cultural and political struggles}

Cultural struggles have been important in Mumbai ever since the creation of the Arya Samaj $^{79}$ (1875). Since 1989, there have been several controversies regarding theatre and books but the most important and visible cultural protests-barring the symbolic community-based ones - were associated with the Shiv Sena or other Hindu nationalists. Since its inception, the Shiv Sena has been convinced that it incarnates Maharashtrian culture but also global culture and common sense. It tried for long, with a mitigated success, to intervene in the process of film production. Several unions and well-known actors are associated with the organization.

For example, the Shiv Sena tried to prevent the diffusion of Mani Ratnam's film Bombay (1995). There were several demonstrations and movie halls were attacked. It finally accepted the love story between a Muslim boy and a Hindu girl portrayed in the movie. The same Shiv Sena was supported by the BJP when it tried to stop the diffusion of diffusion of Fire (a film by Deepa Mehta, about a love story between two women) in the name of good morals in 1996. Some other movies were targeted for the same reasons.

The Shiv Sena and its ageing leadership also tried to counter the fashion of Valentine's Day, with the collaboration of the Bajrang Dal, a branch of the Sangh Parivar that is relatively weak in the city. This action gained momentum after 2005. It was strange to see the Shiv Sena, which has the reputation of being the Party of Love and Marriage among the youth, embarking on such a venture. ${ }^{80}$ Shiv Sainiks publicly burnt Valentine's Day cards and attacked some stalls but they could not stop the practice, even in their own ranks. In 2011 the organization made a U-turn and ceased to target the lovers' day.

Another cultural struggle of the Shiv Sena is also political. It is related to cricket. Several times, the organization's activists tried to stop or sabotage cricket competitions involving Pakistan. Once they ploughed up the pitch at the Wankede stadium. These initiatives were not much supported by the youth.

Mumbai is a political centre. There is a constant flow of Maharashtrian people trying to get the attention of the government and the regional Parliament. Interest groups like the Shektari Sanghatan of the peasant leader Sharad Joshi, professional groups such as the anganvadi workers (village-based development workers) or regional coalitions, such as the movement for Vidharbha, briefly reach the pages of the newspapers. This is the normal life of a metropolis.

Some protests are more specific.

The attempt of Arun Gawli, a notorious gang leader, to create another Shiv Sena (Akhil Bharatya Sena, or ABS), in 1997, brought to light the growing dissatisfaction with the Shiv Sena as a ruling party among its supporters as well as the importance of underworld politicians in the fabric of Mumbai politics and dissent. This ABS immediately got support in the central districts of the city. It organized demonstrations against the 'anti-people policy' of the Shiv Sena-BJP government.

The persistence of non-violent struggles against cow slaughter in front of the great slaughterhouse of Deonar reminds us that that the so-called cosmopolitan city is part of a country with a specific tradition and pervasive historical problems. When randomized, in 
1993, 70\% of Mumbaikars said that they supported such moves, engineered by old Gandhians and Hindu nationalists, and which took place regularly.

The absence of conflicts concerning the environment is a revealing part of the scene, given the conditions of pollution and health hazards that are endured by a majority of the population. The consciousness of environment degradation is the privilege of an educated minority. Indeed, it is very biased. The cause of environmental preservation was invoked several times for destroying slums and industrial activities that were vital for the common people. There is a Bombay (then Mumbai) Environment Group led by the Gujarati-speaking Samir Mehta (1997) but it focused on issues such as the Pune-Mumbai highway which were neither popular nor important in the context.

Yet there were two important environmental struggles.

The struggle against the Enron power plant in Dabhol was as much a nationalist and developmental conflict as an environmental one. It took place between 1993 and 1997, associating a motley coalition of leftist groups, peasants of Konkane and activists of the Hindu nationalist organisation Swadeshi Jagaran Manch. ${ }^{81}$ There were several meetings and demonstrations in Mumbai but the struggle, that Enron's bankruptcy proved later to be justified, failed.

The protest of the fishermen, against the depletion of fish stocks (due to pollution) and the illegal activities of trawlers along the coast, ${ }^{82}$ was truly a popular environmental struggle. It was incarnated by a six-month strike and dozens of demonstrations in 1996. People in Mumbai resented the move because fish is part of the staple of a large share of the population in the city. Morcha and meetings multiplied. There were numerous reports in the newspapers. The fishermen could get nothing.

\section{Concluding remarks}

This review of urban protests in Mumbai during the past twenty years leads us to a series of analytical remarks.

The first concerns the persistence of long-term problems of poverty. The so-called global city is still a third-world city with the classical problems of such cities, in particular the co-presence of a wealthy 'middle class' and considerable urban poverty, and is likely to remain this way for some time to come (Heuzé 2007).

A second remark concerns the end of the workers' movement. Mumbai had been a stronghold of the left, especially the Communist Party of India. This is no longer the case. An intellectual left has remained but it speaks more and more for itself. On the side of the workers, prospects of general strikes are over. Union culture is receding, even at the level of the Shiv Sena Unions. NGOs were unable to replace trade unions and other class organizations. They usually act as expressions of a 'middle class' which is indeed a privileged one. There are certainly different views about 'civil society'. Leftist groups try to give a 'social' content to this notion. My argument is that they failed. They did so because it is not possible to emancipate workers or the poor by using a concept which is relevant for asserting the pressure of the rich and the elite. The next popular subculture which is likely to disappear is that of the Shiv Sena. It is very difficult to tell what will replace it. Commercial trash TV, as it seems to be the case? Or another kind of communal and symbolic assertion? 
It is now possible to outline a typology of urban protests. Firstly, there are protests against the state and the municipal corporation and other public utilities, especially those which are directed against other social groups and communities as in the case of symbolic struggles opposing Marathas and Dalits. Secondly, we can differentiate social struggles (of workers and others), category-wise struggles (rickshaws and taxis for example), survival struggles (for essential items, etc.), struggles about the control of urban space, which were on the rise during the period, and struggles for identity assertion and dignity. These struggles are often combined with electoral fights. Struggles for the control of the city, which are engineered by the rich who do not vote, constitute a specific category. During the period, social struggles receded, when struggles for identity and assertion were on the rise. Other urban protests stayed at a high level. There was an emergence of the three main poles of urban protests among the Sunni Muslims, ${ }^{83}$ the Shiv Sena and the Dalits. The popular element was totally reinterpreted by this emergence. The class dimension clearly receded. During the seventies, despite the existence of the Shiv Sena and Dalits as specific movements, social struggles of workers were very important. Industrial workers led large movements associating housewives, youth, street vendors, rickshaw drivers and others. This was no longer possible after the dramatic end of the textile strike. Workers became a marginalized category. Prospects for global confrontations of the poor versus the rich or the state were annihilated. Very large conflicts arose between popular segments (Muslims and other, Dalits and Shiv Sainiks). ${ }^{84}$ There is still an important popular dimension but it is Hindu OBC and Maratha, Dalit or Sunni Muslim. In the present conditions, the 'popular' cannot be replaced by the 'public' which is an almost exclusively upper caste, upper middle class notion. Residence-based struggles retained a strong class content but they divided the workers and the popular classes (inhabitants of chawls totally lacking solidarity with slum dwellers). Consequently, they were unsuccessful.

The symbolic dimension was associated with a lot of protests. Its importance is related to the receding trend of workers' struggles and organizations. Symbols assumed greater importance because concrete issues, especially those concerning employment and housing, became out of the reach of the popular classes. The Shiv Sena promised to give employment and housing. It failed. Yet, it got 'Bombay' changed to 'Mumbai'. This was political manipulation of symbols but it also brought, rather cheaply, a change of atmosphere. Can symbols be used by the poor? People are not only manipulated through the use of symbols. They are actors of the scene but they proved unable to act outside the local level.

The importance of community feelings, associated to caste, religion and region, has not receded. Community bonds and local level associations are precious to face the 'market forces', which are dismantling the city's industrial basis, and the pressures of the rich for appropriating the city and its space. The trend is strengthened: Dalits, Muslims, Marathi speakers, $\mathrm{OBC}$... These are large groups with specific territories and parties. These processes are connected to the persistence of old ties..$^{85}$ They are also the relevant way of adaptation of poor people migrating to the 'tough city'. Those who claim to stay away from this kind of solidarity, like the rich Parsis or Jains, are indeed well organized at the community level. The difference may be that their consciousness of the community is not painful. It does not lead to open protests.

Riots did not disappear from the scene. It is difficult to include them among urban protests. They are more than protests; they are a kind of war. The persistence of important levels of violence is connected to the Shiv Sena influence but many other 
groups and movements are interested in street violence. This state of affairs is representative of a partly globalized, partly segmented city, globalization accentuating fragmentation.

The impression of division or even fragmentation among the popular milieus is striking. The people of Mumbai were never united. The metaphor of 'popular resistance', which is still used among NGOs, was for long misleading. Nonetheless during the fifties and sixties, even at the beginning of the eighties, there were large movements shaking the whole of society. Since 1989 there has been a spate of struggles of 'the people' against 'the people': confrontations of chawl tenants against hutment dwellers, struggles of rickshaw drivers against taximen, fights of streets vendors against small shopkeepers and so on. The municipal workers, who had been supported by so many people during their historic1958 strike, are presently treated with scorn and considered as 'lazy' by the rich but also by many members of the popular classes. A sizable chunk of 'petty bourgeois' used to lead people's struggles, through the Communist movement or other channels. The scope for such movements is much reduced. There is nonetheless a feeling of being Mumbaikar that express itself in times of crisis (terror strikes of 1993 for example). The city continues to integrate people. It does this, but the process, which was always a difficult one, may become more and more selective.

The evolution of the Shiv Sena changed the scene of protest in Mumbai. B. Thakre's organization $^{86}$ was for long the champion of specific kinds of protest: the locally-based protest about essential services and commodities. It also championed some types of political protest for Maharashtra borders and Marathimanush (Maharashtrian 'son of the soil') pride, etc. It could not completely abandon this kind of posture during its period at the head of the regional government (in alliance with the BJP, a bourgeois party), but its process of gentrification, which began as far back as 1970, was deep and irreversible. Its return to methods of agitation after 2000 is not credible... The MNS tried to reintroduce the violent ways of direct action but it could not get much headway. It is a caricature of the old Sena.

Housing and street vending struggles, related to the control of space and employment for the poor, existed throughout the period. Globally there was a shift of tensions from wages and income related contradictions to space control-related ones. It was a painful process for the majority. More than half the inhabitants are slum-dwellers. The protests of evictees were too weak and scattered to be effective. There was continuous resistance. Yet the city has changed considerably, to the benefit of the rich, during the past twenty years. The Dharavi rehabilitation scandal, which occurred in 2006, is symptomatic: in a large 'notified' (protected) slum, it was decided to oust families and industries in order to build posh residences and a ... golf course under the aegis of the private sector. It is not 'the market', the strange god of the period, but the concrete agents of capitalism (builders, etc.) and the complex groups of dominant classes who are engineering the changes.

The peculiarities of the protests of the rich, the 'well-off', the petty rich and the 'lower middle class' should be reasserted. The bourgeoisie feels oppressed by the 'politicians' as well as by the slum dwellers and other 'illegal' (self-appropriating) 'users' of the town. In these milieus, the fathers did not want Mumbai to stay in Maharashtra. Their children felt discriminated against by the policy of reservations during the Mandal controversy of $1990^{87}$ (there were demonstrations in town but no riots). ${ }^{88}$ There are nonetheless several voices among the rich and 'middle classes'. Some would like industry to disappear more 
quickly from the city. Others still work in industry. The rich need workers and domestic servants, drivers and newspapers sellers, but they would like them to live very far away, without giving a paisa ${ }^{89}$ for solving their problems. They promoted the idea of a harmonious and 'modern' city. The lower 'middle classes' have a special relation to city protests. They often dwell in the vicinity of slums. They feel threatened. They continually pushed forward strongmen in the administration and the police, opposing them to the 'corrupt' politicians. They denounce the city as dirty, violent and inefficient but they worry about the lost 'Bombay village'... These multiple trends are associated with smallscale, but well publicized kinds of protest. In the present media system the petty problems of the rich are much more important than the acute (vital) difficulties of the majority. What is clear at this level is that there is a continuous class struggle between the rich and the poor. What the rich demand-cleaning the streets, razing slums, deindustrialization, prohibition of street sales is basically opposed to the interests of the poor and the people as a whole. Yet, two facts complicate the situation. Firstly, the rich feel underrepresented and victimized by the democratic set-up. This is why they promote quasi-urban protests. Secondly, there is no unity among the poor. People living in the chawls are afraid of those living in the streets (especially their streets) and so on. They listen to the voices of the rich who want to clean the city.

Protests in Mumbai have specific ways but they also belong to types of assertions which are typically Indian and south Asian.

Among specificities, the bandh ${ }^{90}$ is a significant part of the city legacy of protests. It remains a tactic of groups which are sufficiently powerful to confront the police, the state, other political forces and public opinion. Morcha (demonstrations) are common in Mumbai as well as in the rest of urban India but there is probably, under the influence of the Shiv Sena, the Dalit movement and the Muslim community, a particularly dynamic aspect of these protests in the capital of Maharashtra. A very interesting aspect is the articulation of protests such as bandh and morcha, and many other kinds of popular assertions, including small riots, with a very dense and complicated network of local associations. There are thousands and thousands of mandal, mitra mandal and puja samiti (clubs, friends' clubs and religious committees) which structure the processes of mobilization and protest. They are cultural and local associations. They were instrumental in the shift from trade union wage-related activities to religious and nationalist festivals, which were the craze of the period. They also manage space-related tensions. Those who can articulate their movement with such networks, especially the Dalits and the Shiv Sena, have an important presence. It is also true for the bourgeois and petty bourgeois parts of the city population, with the numerous clubs of elites and 'respectable people', despite the fact that their protests are less spectacular.

The shape of the long peninsular city has an influence on the protests. This feature has grown in importance with the extension of daily commuting and the mediatization of the scene. Its geography is so particular that it is enough to block two main roads and the railway nexus of Dadar to stop the entire economic life. This has given a very great importance to blockades such as rasta roko $0^{91}$ and rail roko. Yet, for about ten years, the rich and the authorities tried to prevent meetings and demonstrations. This is mainly efficient with the weak, peaceful movements. Since 2000, it has become less and less easy, because of police bandobast, for the protesters to reach the south of the city, the economic and political heart of the capital of Maharashtra. 
There is an important ritualized dimension of urban protests in Mumbai. This ritualism is a version of a paradigm that exists all over India. Protesters speak very abusively (especially the Dalits and the Shiv Sena), they play with tensions (especially the Shiv Sena), they systematically attack corruption, the state and politicians (especially the rich and petty rich Mumbaikar), and they organize the ritualization of emotion: wrath, disappointment, sadness and, at times, the pleasure of being citizens of such a large and famous city. The "politics of outrage ${ }^{92}$ is a specialized field of protests in Mumbai that can be compared, in this regard, to the situation of Karachi in Pakistan. ${ }^{93}$ Pride was particularly cultivated by Hindu nationalists (Bajrang Dal), ${ }^{94}$ Muslims, the Shiv Sena and the Dalits. Attacks against bureaucrats and middlemen exhibit this ritualism and dramatization but it must be underlined that they have a concrete basis. Bureaucrats are really scornful, politicians corrupt and contractors inefficient. It is ritualism but it is not only ritualism.

I want to finish by saying a few words about the terrorist strikes which have been so prominent during recent years in Mumbai ${ }^{95}$ and which were engineered by Muslim, sometimes Pakistan-based elements. ${ }^{96}$ The politics of bombing seems to attempt to destroy any kind of civilized conduct in the metropolis. It prevents the expression of protests by imposing terror, repressive laws and possibly a police state. Yet, the imagination of a minority of the Muslim youth in Mumbai is engulfed by this policy of terror. The SIMI ${ }^{97}$ was well organized in Mumbai. There are more radical movements. The challenge of getting this youth back to the city dreams and realities is among the most worrying of the present time.

\section{BIBLIOGRAPHY}

Boivin, Michel (2007) 'Violence, défragmentation sociale et tension urbaine: Karachi dans la perspective de la courte durée' in Véronique Dupont et Djallal G. Heuzé (eds.), La ville en Asie du Sud, Paris : Editions de l'Ecole des hautes études en sciences sociales (collection Purushartha), pp. 373-412.

D’Monte, Darryl (2002) The Decline of Mumbai and its Mills, Delhi: Oxford University Press.

Debord, Guy (1967) La société du spectacle, Paris: Gallimard.

Eckert, Julia ( 2003) The Charisma of Direct Action, New Delhi: Oxford University Press.

Gramsci, Antonio (1973) Selections from the Prison Notebooks, London: Lawrence and Wishart.

Gupta, Dipankar (1982) Nativism in a Metropolis, New Delhi: Jain \& Manohar.

Hansen, Thomas Blom (1993) 'RSS and the Popularisation of Hindutva', Economic and Political Weekly, 42(28), pp. 2271-72.

Hansen, Thomas Blom (1999) The Saffron Wave: Democracy and Hindu Nationalism in Modern India, Princeton: Princeton University Press. 
Hansen, Thomas Blom (2008) 'The Political Theology of Violence in Contemporary India', South Asia Multidisciplinary Academic Journal [Online], 2 | 2008, online since 31 December 2008, Connection on 17 January 2012, URL : http://samaj.revues.org/index1872.html

Heuzé, Djallal G. (1987) La grève du siècle, Paris: L'Harmattan.

Heuzé, Djallal G. (1994) ‘Bombay, La Shiv Sena et le territoire urbain’, Hérodote, 71, pp. 149-68.

Heuzé, Djallal G. (2000a) Bombay-Mumbai, en tendresse et en fureur, Paris: Autrement.

Heuzé, Djallal G. (2000b) Bombay en flammes, Le cri des deux mondes, Paris: L'Harmattan.

Heuzé, Djallal G. (2001) 'Le déclin des quartiers ouvriers du centre de Mumbai', Annales de la recherche urbaine, 90, pp.130-137.

Heuzé, Djallal G. (2003) 'Logement des pauvres, médiation politique et contrôle urbain à Mumbai, Inde', .Autrepart, 25, pp.153-167.

Heuzé, Djallal G. (2007) ‘Mumbai, première ville de quoi?' in Isabelle Berry-Chikhaoui, Agnès Deboulet \& Laurence Roulleau Berger (eds.) Villes internationales, Paris : La Découverte, pp.42-54.

Jacobson, Mark \& Bendiksen, Jonas (2007) 'Dharavi, dans l'ombre de Mumbai', National Geographic, 92, pp. 78-103.

Jaoul, Nicolas (2006) 'Learning the use of symbolic means. Dalits, Ambedkar statues, and the state in Uttar Pradesh' Contributions to Indian Sociology, 40 (2), pp. 175-207.

Laine, James (2003) Shivaji: Hindu King in Islamic India, Oxford: Oxford University Press.

Padgaonkar, Dillip (1993) When Bombay Burned, New Delhi: UBS Publications.

Patel, Sujata \& Thorner, Alice (eds.) (1995), Bombay, Metaphor for modern India, Delhi: Oxford University Press.

Patel, Sujata \& Masselos, Jim (eds.) (2003) Bombay and Mumbai, New Delhi: Oxford University Press.

Purandare, Vaibhav (1999), The Sena Story, Mumbai: Business Pub. Inc.

Savery, Aurelia \& Fernandez-Alvarez, Irène (2006) Girangaon à Mumbai, Mémoire pour le Diplôme d'architecture, Ecole d'architecture de Paris-La Villette.

Sharma, Kalpana ( 2000) Rediscovering Dharavi, New Delhi: Penguin Books.

Sundaram, P.S.A. (1989), Bombay. Can It House Its Millions? New Delhi: Clarion Books.

Tindall, Gillian (1982) City of Gold, New Delhi: Penguin Books.

Van Wersch, H. (1992) Bombay Textile Strike, Delhi: Oxford University Press.

Weiner, Myron (1988) Sons of the Soil, New Delhi: Oxford University Press.

\section{NOTES}

1. I will write 'Mumbai', notwithstanding the fact that other names were in use for long periods.

2. Dalit: former Harijan (child of God) -a Gandhian view- or Untouchable. Untouchability was abolished in 1950 and outlawed in 1955, 1989.

3. References of newspaper articles (which have been relied upon in large numbers) are not provided here. 
4. The Samkhya elaborates a three-tier world of affects and qualities (guna). Sattva (white) is the truth associated with the Brahmanic order. Rajas (red) is bravery associated with Kshatriyas (warriors). Tamas (black) is connected with other classes and with low feelings.

5. The word 'communal' has a special connotation in India. It belongs to a specific demonology. It is associated with a very particular colonial past and to the partition.

6. Designated as such in 1876 by the British.

7. 99 people were killed by the police during a demonstration in November 1955.

8. The Indian National Congress (INC, created in 1885) that led the national struggle gave birth to several parties in 1947-1951, including the centrist Congress Party. This party was recently renamed as INC, a step which is a historical forgery.

9. Present urban projects are going to change this situation. A metro, bridges and expansion of the train transportation system are currently being completed.

10. 'People' is not a satisfactory category but it permits us to gain space. Usually, I will consider as such: wage earners, municipal corporation employees, industrial workers, especially in the informal sector, street vendors, bus, train, taxi and rickshaw drivers, small shopkeepers and some school teachers.

11. I find that 'middle class' is a globally confusing and forcefully ideological notion. It is a byproduct of the ideology of the affluent society (and before that of the Victorian dream of the generalized bourgeoisie). It has been renewed and aggravated by the recent free market ideology. Yet Marxist categories such as bourgeois (petty, middle or big) or dual appreciations such as 'the rich' and 'the poor' are also sources of problems. There is a great need for reinventing a typology of the people in the cities of 'the South' today.

12. 'Sons of the soil' movements are important social trends that claim rights for the people of one region or state. They can adopt several kinds of political postures (see Weiner 1988).

13. It is often written that the textile strike began on January $16^{\text {th }}, 1982$. That is the official beginning, yet, three month before, eight units of Worli, which were the most important and the most assertive, went on strike and opened the way for a city-based, strong movement. This possibility was closed by Datta Samant who opted for the traditional way.

14. Datta Samant was a trade union leader who had numerous successes in improving workers' situation in other industrial sectors. He was consequently chosen by textile workers to be their leader in the last important textile strike in Mumbai (1981-1983).

15. See the movie Hamara Shaher (Anand Patwardhan 1985).

16. See notions of the subaltern in Gramsci (1973) and regarding Mumbai, in Heuzé (2003).

17. The leadership of the Shiv Sena was a part of the subaltern elites. Organizing people's movements, they were neither poor nor 'popular' (there are exceptions).

18. Religion is quoted in the census. Caste - jati - was not, for seventy years. It was reinstated in 2011.

19. About 30,000 people were killed during the revolt of a part of the Sikh youth in Penjab between 1983 and 1995. In that State Hindus were targeted and thousands died. Tens of thousands were displaced in camps.

20. In 1984, following the assassination of the Prime Minister Indira Gandhi by her Sikh bodyguard, thousands of Sikhs were murdered all over India.

21. The judicial enquiry did not reveal the truth.

22. It has another location in the city of Nagpur.

23. It is called the 'unorganized sector' in India. It concerns factories and offices employing less than 10 or 20 people but also farms and self employment. Indeed, small enterprises (less than 50 workers) often have unfair labour practices.

24. Bhivandi, located in the north-eastern part of Mumbai, is not part of the municipal territory but is an important element of the metropolitan economy with large numbers of small-scale textile and manufacturing units. 
25. These States have different labour laws and several of them, such as Gujarat, try to practise social dumping.

26. There were numerous other unions close to the Shiv Sena. Indian National Trade Union Congress (INTUC), the trade union of the Congress Party, shares the same ideology regarding class struggle, but has different practices. Bharatiya Mazdoor Sangh (BMS) from the BJP also shares the 'no class struggle', productivist ideology.

27. The grip of conservative, pro-management and officious unions is not new in Mumbai. The INTUC affiliated RMMS (Rashtriya Mill Mazdoor Sangh) of the textile industry in one of the main examples. The difference is that previously, workers resisted RMMS and other pro-management unions.

28. Like J. Anand, N. Panjwani, etc.

29. The New Economic Policy is a set of pro-market and pro-rich reforms that opened the country to foreign investment. It was the official beginning of globalization.

30. Indeed these practices of the press were older. A medium like the Times of India had a very long history of refusing to take into account workers' struggles.

31. BEST also comprises electricity generation. It is a well managed and efficient service.

32. 'Block the way', 'block the rail' agitations.

33. However the protest had also a juridical extension and a new litigation is taking place.

34. See Heuzé 2001.

35. The municipal commissioner G.R. Khairnar (infra) alone got 240,000 'structures' destroyed between 1990 and 1995, according to his own claim.

36. It was also a negation of the cosmopolitan view. Ten years later Maharashtra pride had no problems with globalized perspectives. The Shiv Sena involved itself deeply in pro-market and pro-rich policies. It deliberately avoided criticizing foreign capital.

37. The contradiction between the two slogans was secondary to the choice of beautification, i.e. the cleaning of unsightly hovels and slums.

38. Voting cards were distributed in the slums on a large scale in 1976 and 1984 by the Congress Party- dominated administration.

39. The question of Bangladeshi migrants was regularly revived by the party leadership, especially in 1995, when it tried to impose permits to get access to the town. The proportion of Bangladeshi seems small (less than 0.5\%).

40. Regarding the RPI case it must be noticed that numerous Dalits stay in slums and it is quite natural for the party to stay on their side since Dalits constitute its main political base.

41. A campaign promoted by NGOs during the eighties demanded that housing become a basic right. It failed.

42. There are also relatively rich people in slums, though they are in the minority.

43. The main dam was inaugurated in $2006.300,000$ people were displaced. The whole project will displace one million people.

44. She created the People's Political Front, supporting from outside the Congress-led coalition, in 2004.

45. The role of this 'world class' firm in the shaping and demolition of Mumbai was very important. They have been giving regularly their - very expensive - advice since the sixties.

46. The kholi is a kind of cell inside a chawl where an entire family lives. There is also a common collective space. This housing is miserable but it is very much coveted in Mumbai.

47. Yet some NGO activists could become municipal councilors.

48. The electoral and symbolic importance of the Shiv Sena in Mumbai during the study period was irregular but always noticeable. In 1985 it got the corporation's full control for the first time after having been the main opposition force since 1968. It lost it in 1992 and regained it in 1997 till now. In 1995 it won all Parliamentary seats barring one, and a large majority of the Assembly 
seats of the metropolis. It is also important in the town of Thane (industrial suburb) and in Navi Mumbai.

49. Navalkar is a writer and an intellectual. He was among the Shiv Sena founders. He led several 'civic' and moral crusades.

50. It has no political affiliation and its leftist commitment is weakening.

51. Shopkeepers themselves have problems, especially about taxation, and intervened several times on the public scene by closing shutters and, at least once, by organizing morchas.

52. Bhayander is outside the Municipal Corporation but is part of the metropolitan region.

53. The 20 year-long Hindu nationalist mass movement that began in 1983 centred on the problems of Hindu pride and identity (see Hansen 1993). Riots also broke out in northern suburbs of Mumbai in 1984.

54. The Shiv Sena has a long and fundamental history of parochialism. The movement opposed Tamils, people from Uttar Pradesh, Gujaratis, Kannadigas and others by claiming special rights for the Maharashtrian 'sons of the soil'. The more recent tussle with Biharis is related to employment problems but also to cultural issues (the Chhat Puja festival celebrated by the Biharis is not appreciated by the Shiv Sainiks) (Purandare 1999).

55. Other Backward Classes are a large, heterogeneous, residual category designating the people who stand in between the upper castes and the Dalits - to put it very simply.

56. Marathas are a dominant caste, comprising $30 \%$ of the population (with several sub-castes). Their status is changing, from rather low to rather good. They have had strong community organizations since the end of the 19th century.

57. The 'Movement for a United Maharashtra' was created by a coalition of opposition parties, mainly leftist, and individuals in 1954. It wanted to promote a 'linguistic state' on the model of Andhra Pradesh which had been created the year before. It was opposed by Nehru, who opposed 'linguistic states', and by the local Congress, dominated by people of Gujarati origin.

58. Shivaji was a Maratha leader who fought the Mughals in the $17^{\text {th }}$ century.

59. Laine 2003.

60. The Shiv Sena refused to be involved.

61. Bhim Rao Ambedkar (1891-1956), Marathi speaker, leader of the Dalit movement between 1927 and 1956. He wrote a large part of the Indian Constitution.

62. The reaction against the destruction of the mosque in Ayodhya had something deeply symbolic and several other occasions saw a large scale mobilization of Muslims for identitycentred and symbolically important purposes.

63. There were nine groups in the Republican Party of India in 1994, then a brief union happened in 1996, followed by other splits.

64. Marathwada, around Aurangabad, is located in Maharashtra, about $300 \mathrm{~km}$ from Mumbai. It was formerly in the princely state of Hyderabad.

65. They belong to higher castes and dominant (numerous and powerful) ones.

66. See Jaoul 2006.

67. Yet the Shiv Sena has good and deep relationship with some Dalits but not with Ambedkarite communities, especially the Chambhar (of Dharavi) and the Koli.

68. The Shri Krishna Commission was mandated to identify those responsible for the 1992-1993 riots in Mumbai.

69. The Sangh Parivar gathers other Hindu nationalist organisations which have a noticeable presence in Mumbai. The BJP and the Shiv Sena have been allied since 1989. The Minorities Commission was reinstated in 2000.

70. The bourgeois parts of Mumbai prefer calling themselves 'Mumbaite' or 'Bombayite' rather than 'Mumbaikar', 'Mumbaivala' or 'Bambaivala', which are more popular terms.

71. They are usually higher caste professional workers such as medical practitioners. 
72. There is a large proportion of Gujarati speakers who are poor, but the Gujarati elite may total $5 \%$ of the inhabitants, which constitutes an important number, not far from one million people. About $14 \%$ of the people, including the Parsis (0.75\%), speak Gujarati.

73. There are 300 to 500 murders a year (among 15 million inhabitants), much less than in Paris (400 murders for 5 million). It could be under estimated however.

74. Mumbai has the largest concentration of rich people in South Asia.

75. The Scout movement remained restricted to the rich classes in India. It was introduced in 1918.

76. A kind of non-violent demonstration referring to the Gandhian saga.

77. Many of these associations are managed by retired people who have both time and social and human capital to deal with the State apparatus.

78. He could be compared to Jagmohan in Delhi but he was not a rich man and he never supported the Hindu Right.

79. The Arya Samaj is a Hindu reformist sect that opposed idolatry practices.

80. Representatives argued that they were not opposed to love but to foreign symbols.

81. This organization was created by the Rashtriya Svayamsevak Sangh, which is one of the main actors of the Saffron wave.

82. Trawlers are not allowed to fish near the coast, the zone being the preserve of small fishermen. They deliberately flout this legislation.

83. Specific communities of Muslims such as the Khojas, Bohras and Konkani Muslims are not part of the Muslim urban protests.

84. Note that there is an elite of rich people in the Shiv Sena as well as among the Muslim and (to a lesser extent) the Dalit communities.

85. Yet during the study period, an important part of the city dwellers abandoned their linkages with the villages, even in the working class and street vendor groups.

86. The Shiv Sena leadership is organized around the Sena Pramukh (main commander) Bal Thakre, succeeded by Udhav Thakre (his son) but there is a circle of a dozen other important leaders, that also has an important role.

87. In 1990 the Indian government announced its intention to implement part of the recommendations of the Mandal Commission, i.e. to introduce substantial quotas for OBCs in public employment.

88. It provoked a split in the Shiv Sena.

89. A rupee is divided into 100 paise.

90. From the Hindi bandh karna (to close).

91. From the Hindi rukna (to stop).

92. See Samaj $n^{\circ} 2$ on 'Outraged Communities' ( http://samaj.revues.org/index234.html), especially Hansen 2008.

93. See Boivin 2007.

94. A youth organisation of the Vishva Hindu Parishad, another main actor of the Saffron wave.

95. There was so much fuss about the November 2008 attacks that other attacks, especially that of August 2006 that killed many more people, were forgotten (they did not target rich people). The metropolis is itself a symbol.

96. Recently Hindu groups have begun to use terrorist methods.

97. Students Islamic Movement of India, banned in 2002. It was a very active movement which was not opposed to terror strikes. 


\section{ABSTRACTS}

The paper aims at understanding the types, scope and contents of urban protests in Mumbai for the past twenty years. Firstly, it tries to define the nature of mass struggles within the city. Then it deals with the rather violent history of the city in the past twenty years. Thirdly, it describes the different types of urban protests and their evolution over time. Finally, it offers a typology of urban protests and discusses the changes occurring in the popular milieus. The class content of the 'popular' (which is not altogether dead) has been increasingly fragmented by a process of community-based assertion that led to protests led by groups representing small categories of the popular classes. In the period studied, workers' struggles were lost while the more recent assertions of the rich who launched (near) urban protests were acknowledged and listened to. This segmentation helps to understand the limits and the ambiguousness of 'civil society' rhetoric.

\section{INDEX}

Keywords: Mumbai, metropolis, protests, struggles, popular, class, community, Shiv Sena, Muslims, Dalits, civil society

\section{AUTHOR}

\section{DJALLAL G. HEUZÉ}

Senior Fellow, CNRS - Centre d'Anthropologie Sociale, Toulouse 